\title{
The Energy Transition in Rural China
}

Jiang Leiwen (Leiwen_Jiang@brown.edu)

Brian C. O'Neill (oneill@iiasa.ac.at)

\section{Approved by}

Leen Hordijk (hordijk@iiasa.ac.at)

Director

December 17, 2003

Interim Reports on work of the International Institute for Applied Systems Analysis receive only limited review. Views or opinions expressed herein do not necessarily represent those of the Institute, its National Member Organizations, or other organizations supporting the work. 


\section{Contents}

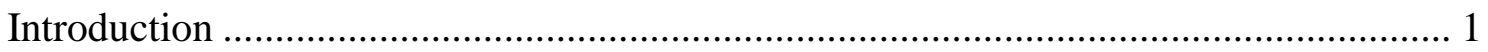

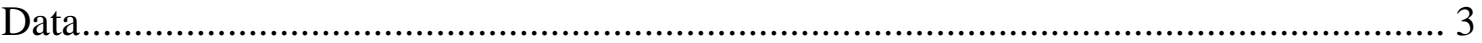

Rural Household Energy Consumption ...................................................................... 5

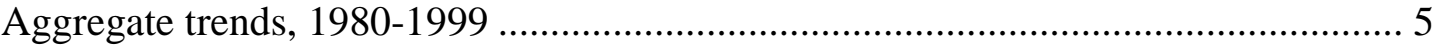

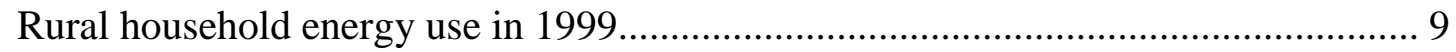

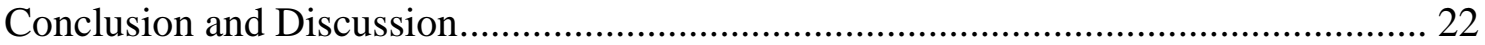

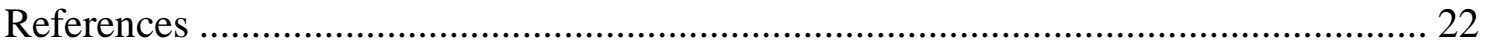




\section{Abstract}

Based on an analysis of a nationally representative rural household survey and various sources of aggregate statistics, we explore patterns of residential energy use in rural China within the conceptual framework of the energy transition. We find that residential energy consumption varies tremendously across geographic regions due to disparities of access to different energy sources, prices, climate, income, and urbanization level. Household demographic characteristics, in particular household size, have important impacts on residential energy use. Aggregate time series data show that the transition from biomass to modern commercial sources is still at an early stage, and crosssectional data suggest that incomes may have to rise substantially in order for absolute biomass use to fall. We also find that energy use patterns as a function of net income, rather than total expenditure, are more consistent with the energy transition model in rural China. 


\section{Acknowledgments}

This research was supported by the Office of Science (BER), U.S. Department of Energy, Grant No. DE-FG02-01ER63216.

This paper is in press at the International Journal of Global Energy Issues. 


\section{About the Authors}

Dr. Leiwen Jiang is an Assistant Professor (Research) in the Global Environment Program, Watson Institute for International Studies, Brown University, Providence, Rhode Island, USA. He is also an Associate Professor in the Institute of Population Research at Peking University.

Dr. Brian O'Neill is a Research Scholar at IIASA, and Assistant Professor (Research) at the Watson Institute for International Studies, Brown University. 


\title{
The Energy Transition in Rural China
}

\author{
Jiang Leiwen and Brian C. O'Neill
}

\section{Introduction}

More than half of the world's population lives in rural areas, and about $40 \%$ of the rural population lives in China. The majority of rural residents are dependent on traditional fuels, which include various forms of biomass, and these households often use inefficient end use technologies. For many, this combination barely allows fulfillment of basic needs for cooking, space heating, and lighting. Moreover, heavy reliance on biomass has raised pressing concerns over the health impacts of indoor air pollution, as well as over environmental consequences such as deforestation and soil erosion. Strategies to address these issues include both improved efficiency of energy technologies and fuel switching from biomass to modern energy sources, which reduces emissions due to higher efficiencies and lower emission factors (World Energy Council 1999; Adeoti et al. 2001; Wijayatunga and Attalag 2002).

Over the past several decades, many studies have observed that the process of economic development is generally accompanied by a shift within developing country households toward increasing use of modern fuels, and decreasing reliance on biomass, even in the absence of policies explicitly aimed at achieving this outcome. Understanding this "energy transition," as it has come to be called, is therefore of prime importance for designing policy interventions. It is also important for energy planners who must anticipate future demand for different types of fuels, as well as for those concerned with the longer-term environmental consequences of energy use, such as climate change due to the emissions of radiatively active trace gases.

However even some basic features of the energy transition remain unclear, and literature on the topic is plagued by differences in definition as well as by emphases on alternative explanatory variables and processes. For example, the energy transition is most commonly defined as a decrease in the proportion of household energy derived from biomass. However, this outcome could occur under a variety of conditions: (1) a decrease in the absolute amount of biomass use, driven for example by the substitution of modern for traditional fuels, while total household energy use could increase, decrease, or remain unchanged; (2) no change in the absolute amount of biomass use, while use of non-biomass energy increases, so that total household energy use increases; or (3) an increase in biomass use while non-biomass use increases even faster. Each of these conditions would have consequences for health and environmental impacts that differed not only in magnitude but possibly in direction as well. If the energy transition occurs because modern energy substitutes for biomass and leads to a decline in its use in absolute terms, ecological pressure and health impacts could be eased. Conversely, if 
the energy transition leads to increases in the use of all types of fuels, these problems could be exacerbated.

Whether there are generalizable features of the energy transition in terms of absolute quantities of energy use ${ }^{1}$ is unclear. Studies in Mexico (Sheinbaum et al. 1996), South Africa (Davis 1998), China (Wang and Feng 1997), and India (Reddy 2003) all find evidence of the energy transition in both urban and rural settings, but there is no consensus on the consequences of the transition for the absolute amount of total and biomass energy use. For example, while most studies suggest that the process of energy transition increases total energy use per capita, the World Energy Council (1999) finds that, at least initially, total energy consumption may decline as more efficient, modern energy technologies are introduced, while Foster et al. (2000) find an inverted U-shaped relationship between per capita income and gross energy consumption in Guatemala.

Regarding the consumption of biomass energy in particular, Leach and Gowan (1987) and Leach (1992) argue that a basic feature of economic growth, with its associated urbanization and industrialization, is the substitution of modern fuels for traditional biomass fuels, and hence a decline in absolute biomass use. The preference for modern fuels is driven by the fact that they are relatively clean, highly controllable in terms of power output, and do not have to be collected. However, while increasing evidence suggests that such a transition is rapidly occurring in urban areas of developing countries, the present situation and prospects for rural areas are much more uncertain. For example, Foley (1995) argues that substitution is not a major feature of the energy transition in rural households. Rather, these households almost invariably collect biomass fuels from the immediate surroundings to meet their basic needs for energy for cooking and space heating. As economic circumstances improve, additional demand is satisfied by commercial energy sources, but biomass use continues. Evidence for limited substitution of, for example, kerosene for biomass has been found in Indonesia (Pitt 1985; Leach and Gowan 1987) and Mexico (Sheinbaum et al. 1996).

Regarding the determinants of the energy transition, the literature has reached some consensus but important questions remain. Studies tend to agree that income is a key determinant of total energy demand, although even here studies can be difficult to interpret and compare due to the use of different measures of income, a topic we return to later in the paper. Almost all studies find that household size is another key determinant of demand, with per capita energy use smaller in larger households due to economies of scale. Changes in Mexican household size were even more important than income in determining per capita energy demand between 1970 and 1990 (Sheinbaum et al. 1996). Beyond these basic determinants, some researchers emphasize the importance of infrastructure for modern fuel distribution; after such infrastructure is in place, and households have access to and begin to use a variety of fuels, energy prices (and biomass scarcity) then drive shifts in fuel mix within households (Leach 1992). A study in South Africa, however, found that infrastructure has been of little importance (Davis 1998). Others single out the cost of end use technologies as the main hurdle for rural families to adopt modern fuels in India (Reddy 2003) and Nigeria (Adeoti et al. 2001).

\footnotetext{
${ }^{1}$ Energy use in this paper means primary energy use, i.e., the heat content of the fuel used to produce the final energy.
} 
Given that the process of energy transition in rural households is not well understood, and the important health and environmental issues raised by this process in China, it is important to have a clear picture of current conditions in this country and a well-grounded outlook for the future. However all existing analyses are based on aggregate statistics (Wang and Feng 2001) or on surveys conducted in one county or province (Wang and Feng 1997; Wang et al. 2002; Wang et al. 1999), or in several counties (ESMAP 1996; China Academy of Forest Research 2003). Here we undertake the first analysis of a nationally representative survey of rural households in China to describe patterns of rural energy use in the context of the conceptual framework of the energy transition. In the next section we describe the dataset. Following that we present a descriptive analysis focusing on patterns of energy use by income, as well as a regression analysis of the determinants of total energy use and the proportion derived from biomass. Finally, we provide a discussion and summarize conclusions.

\section{Data}

Data used in this study are from the 1999 National Rural Household Survey, an annual survey conducted by the China Rural Socio-Economic Survey Division of the State Statistical Bureau. The rural survey started in 1965 and covered a national sample of households. Each household was required to keep a record of income and expenditures and received a small payment in return. The survey ceased during the Cultural Revolution in 1966-1976, and resumed in 1977. The questionnaires and sample sizes have expanded in recent years. In order to avoid the problem of sample aging, provision was made for the annual replacement of a proportion of the households, such that the entire sample was replaced every four years. Before 1990, the rural household surveys did not contain useful information on energy use. Since 1990, questions regarding energy use were gradually included in the survey. By the end of the 1990s, the questionnaire included sufficient detail to provide a general picture of household energy use. However, beginning in 2000, the survey no longer included information on total biomass use, which is still the major energy source for rural households.

We obtained a $\sim 80 \%$ random sample of the 1999 rural household survey dataset; our sample includes 48,384 households, and 208,564 household members. The dataset contains variables on household's and all household members' demographic characteristics (sex, age, occupation, education, and marital status), income, expenditure, and durable goods (including domestic appliances). Energy-related information is provided by fuel (electricity, coal, coal product, charcoal, fuelwood, grass and agricultural residues, and others - mainly liquefied petroleum gas (LPG) - hereafter referred to as "LPG+", ), separately for purchased energy and total energy. Total energy use can differ substantially from purchased energy for some fuels because many rural households collect biomass, and sometimes coal, from surrounding areas. For purchased energy, the dataset includes information on expenditures and quantities of coal, coal product, charcoal, and LPG+. For purchased electricity and biomass, only expenditures

\footnotetext{
2 The 1999 rural household survey lumps all fuels other than biomass, electricity, and coal into the category "other fuels". According to the State Statistical Bureau (2001a), kerosene consumption in the residential sector accounts for only $0.5 \%$ of total energy use in 1999. Among other fuels, LPG accounts for $45 \%$, natural gas $11 \%$, and piped gas $40 \%$. However, in rural areas piped gas is rare. Therefore, LPG is the dominant fuel among "other fuels".
} 
are provided. For total energy, the dataset provides expenditures by fuel, where expenditures include actual expenditures for purchased energy plus an estimate of the value of the collected fuels. We calculate total quantities of consumption by fuel type by calculating prices based on the quantity and expenditure data for purchased energy, and applying these prices to the data on total expenditures by fuel. Since quantities for purchased biomass and electricity are not included in the 1999 survey dataset, we estimate prices from separate sources. For electricity, we obtained prices for each of 343 prefectures from various volumes of documents issued by the China State Planning Committee. For biomass, we calculate the price for each of 841 counties from the 2000 rural household survey dataset. For most counties, there is not an actual market for fuelwood or agricultural residue, so prices are generally estimated by the interviewers. The prices are used to convert the total amount of biomass use reported by a household into a market value. Interviewers are generally official staff members of local statistical bureaus. According to the director of National Rural Household Survey Division of the State Statistical Bureau (personal communication), biomass price estimates do not change substantially from year to year. Thus, our use of the 2000 prices as an estimate of the 1999 prices is unlikely to introduce substantial errors into our analysis.

The energy use calculated for each fuel represents final energy demand by households. For the purposes of aggregation and consistent comparisons, we convert final energy demand for each fuel into kilograms of standard coal equivalent (kgce). This measure is referred to in China as "standard coal efficiency units" and is close to, but not exactly the same as, primary energy use. ${ }^{3}$ As commonly defined, primary energy consists of final energy plus (1) losses in conversion from primary to secondary energy, (2) energy used by conversion plants, and (3) transport/transmission, distribution, and storage losses. In contrast, standard coal efficiency units do not include transport, distribution and storage loss. The difference between standard coal efficiency units and primary energy is largest for electricity, and in that case amounts to about $8 \%$. Table 1 gives conversion factors per physical unit of final energy consumption to (1) final energy demand in common energy units using the heat content of the fuels, (2) standard coal efficiency units, and (3) primary energy. We use standard coal efficiency in our analysis in order to compare to published aggregate statistics, unless otherwise noted.

\footnotetext{
${ }^{3}$ The China State Statistical Bureau also refers to standard coal efficiency units as "final energy". We do not use this term because it would conflict with the commonly accepted definitions of final energy. The standard coal efficiency conversion factor for electricity is about $0.404 \mathrm{kgce} / \mathrm{kWh}$. In recent years some Chinese government departments have adopted the approach used by other countries (and the International Energy Agency) of converting kWh of final energy demand to standard energy units by the heat content of the electricity itself, rather than including conversion losses as well. The resulting measure of final energy demand is also known as "site energy" or, in Chinese statistics, "calorific equivalent" (David Fridley from Lawrence Berkeley National Laboratory, personal communication in 2002). This conversion uses standard factors of $860 \mathrm{kcal} / \mathrm{kWh}$ or $3596 \mathrm{kjoules} / \mathrm{kWh}$, or $0.1229 \mathrm{kgce} / \mathrm{kWh}$ (see Table 1). Given the substantial difference between the two factors, it is important to know which conversion system is being used, particularly while making international comparisons.
} 
Table 1. Index of standard coal efficiency conversion of all types of energy.

\begin{tabular}{llcc}
\hline Energy type & Unit & $\begin{array}{c}\text { Standard coal efficiency } \\
\left(^{\text {Kgce/unit) }}{ }^{\mathrm{a}}\right.\end{array}$ & $\begin{array}{c}\text { Thermal efficiency } \\
\text { (kilocalorie/unit) }^{\mathrm{b}}\end{array}$ \\
\hline Coal & $\mathrm{Kg}$ & 0.7143 & 20,908 \\
Fuel oil & $\mathrm{Kg}$ & 1.4714 & 43,070 \\
Kerosene & $\mathrm{Kg}$ & 1.4571 & 42,652 \\
Diesel & $\mathrm{Kg}$ & 1.4571 & 50,179 \\
$\mathrm{LPG}$ & $\mathrm{Kg}$ & 1.7143 & 46,055 \\
Natural gas & $\mathrm{Cubic}$ meter & 1.3286 & 17,354 \\
Electricity & $\mathrm{kWh}$ & 0.4040 & 11,825 \\
Firewood $^{\mathrm{c}}$ & $\mathrm{Kg}$ & 0.4900 & 3,596 \\
\hline
\end{tabular}

${ }^{\text {a }}$ Statistics Reporting System on Energy, Oct. 1986, China State Statistical Bureau

${ }^{\mathrm{b}} 1 \mathrm{kgce}=11,825$ kjoules $=11,216$ BTU

${ }^{c} \operatorname{ESMAP}(1996$, p. xi)

\section{Rural Household Energy Consumption}

\section{Aggregate trends, 1980-1999}

We begin our analysis by briefly reviewing trends in energy use based on aggregate statistics reported by various government bureaus. Over the decades of the 1980s and 1990s, commercial energy consumption in China more than doubled (Figure 1), and China became a major energy importer. The growth of commercial energy consumption reversed in recent years. Data more recent than 1999 are not yet available, but preliminary indications suggest that energy use has begun to rise again (Fridley et al. 2003). Residential energy use represents the second largest sector (after industrial) for commercial energy consumption, accounting for $12-18 \%$ of total consumption in the past two decades. However, this proportion (and Figure 1, on which it is based) understates the importance of residential energy use because it does not include biomass fuel use, which is a principal energy source for rural households, used mainly for cooking and space heating. Data on biomass energy use are scarce and are usually based on estimates provided by the Ministry of Agriculture. These estimates can only be taken as a rough guide to the magnitudes and trends in biomass energy use (Sinton and Fridley 2002). Taking into account these uncertainties, a conservative estimate is that including biomass would increase the residential share of total energy use in 1996 by a further 12 percentage points. All told, residential energy use therefore accounts for about $26 \%$ of total energy use in $1996 .^{4}$

\footnotetext{
${ }^{4}$ If energy use were measured in terms of primary energy, rather than standard coal efficiency units, the result would be little changed. Converting to primary energy use by accounting for transmission and distribution losses increases the residential proportion of total energy use in 1996 by only 0.2 percentage points.
} 

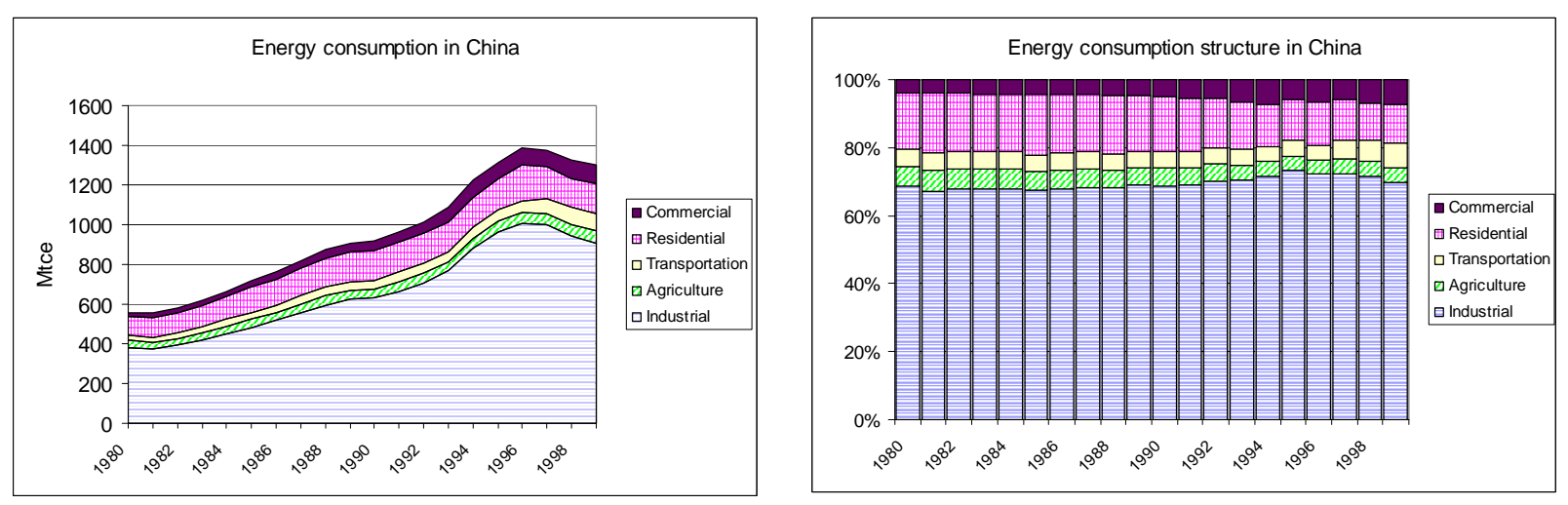

Figure 1. Commercial energy use in China (1980-1999). Source: Department of Industry and Transport Statistics, National Bureau of Statistics (2001).

Figure 2 shows trends in rural household energy consumption, and differs from Figure 1 both in its focus on rural households as well as in its inclusion of biomass energy (note that separate aggregate data for urban and rural commercial energy use are not available after 1996). It also shows per capita, rather than total, energy use. Per capita rural household energy use generally increased from 1980 to 1996 (Figure 2) by about $14 \%$, while the share of energy from biomass fell from $84 \%$ to about $60 \%$. However, the patterns of change for this energy transition are different for the 1980s and 1990s. During the 1980s, the use of both biomass and commercial energy increased; since commercial energy use increased faster, the proportion of biomass energy fell. In the 1990s, the use of biomass fell in absolute terms, so that even though commercial energy use increased rapidly (by 79\% between 1990 and 1996), total energy use remained fairly stable in per capita terms at between $370 \mathrm{kgce}$ and $400 \mathrm{kgce}$. The decline in the proportion of energy from biomass accelerated during this period. Examining the two main components of biomass fuels shows that the use of agricultural residues (straw and stalk) has remained essentially constant over the whole period, while the use of fuelwood first increased in the first decade, and then decreased in the next. 


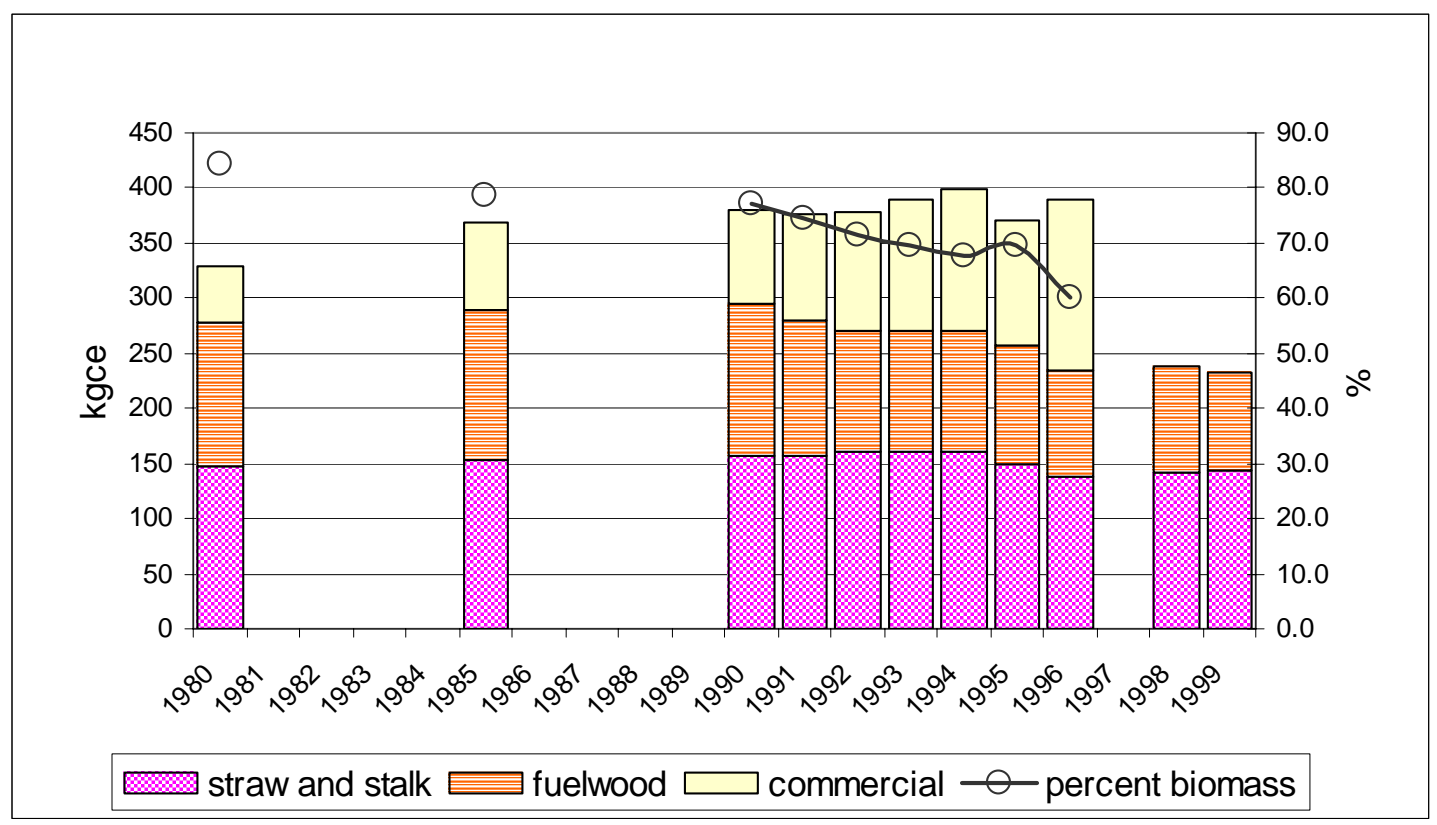

Figure 2. Rural household per capita energy use of China (1980-1999). Sources: Data for 1980-1996 is taken from Transportation and Energy Department, State Planning Committee (1997); data for 1998-1999 is taken from Department of Industry and Transport Statistics, National Bureau of Statistics (2001).

This pattern of change in rural household energy consumption in the past two decades has been affected by many economic, social, and politic factors. One key factor may have been patterns of income growth. While China as a whole has experienced rapid economic development, the growth has been geographically uneven. Rural household incomes increased significantly in most of the1980s, but gains slowed down at the end of 1980s and in the early 1990s before resuming a rapid increase (Figure 3). Before the 1980s, rural households suffered serious energy shortages. Improved economic conditions allowed rural households to increase significantly their energy consumption in the form of both biomass and commercial energy in order to meet their basic needs. In the 1990s, biomass scarcity, in addition to income growth, may have also played a role in declining biomass use. Moreover, new environmental regulations aimed at curbing worsening land erosion, desertification, and river sedimentation may have limited access. For example, many rural areas closed off access to mountains to allow reforestation. In the meantime, the accessibility of electricity, coal and other modern fuels in rural areas continuously improved, and with rapidly increasing incomes since the mid-1990s, demand for electric appliances grew (Figure 4). These factors may have combined to shift energy consumption further toward commercial energy sources. 


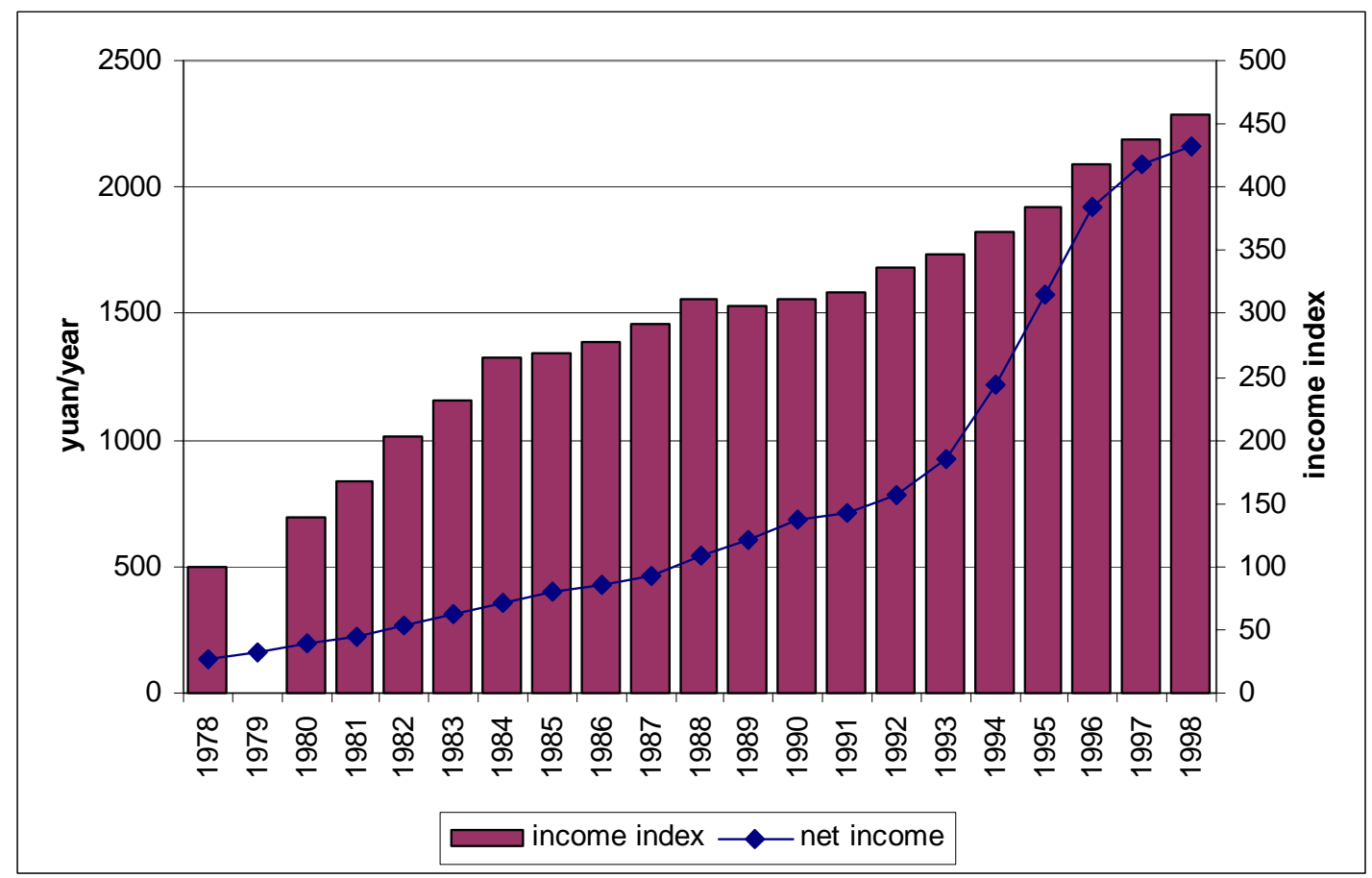

Figure 3. Changes in rural household per capita income. Note: Income index is adjusted for inflation and sets the income of $1978=100$.

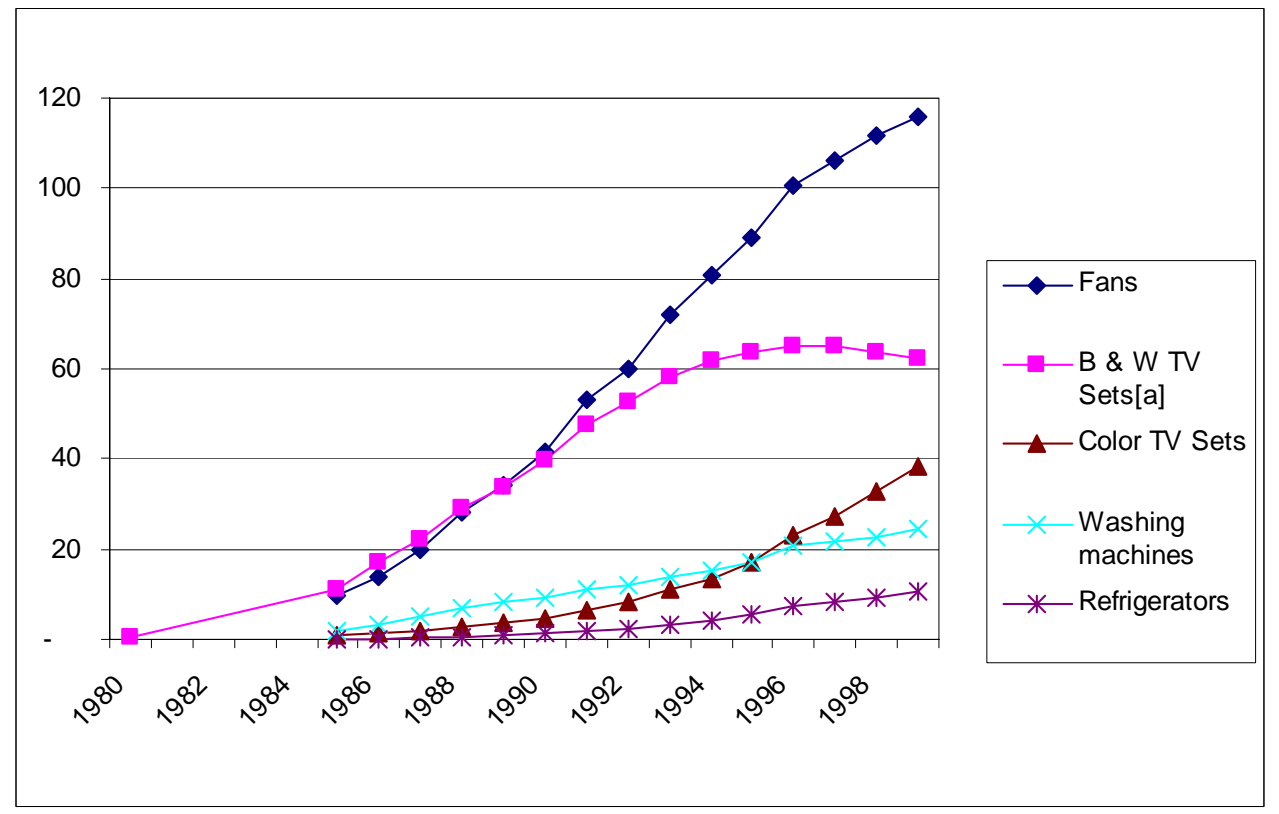

Figure 4. Appliances per 100 rural households in China. [a] Black and white TV sets in 1980 include the very small number of color TV sets. 
The discussion at the macro level above provides a general picture of the energy transition for rural households in China. It suggests that the transition may have taken place in two different stages: First, at relatively low income levels, demand for all fuels increased, but use of commercial energy increased faster than the use of biomass. Next, at higher income levels, commercial energy use continued to grow, but the use of biomass declined as preferences for fuel types shifted. In the next section, we use the micro data to address more specific questions: (1) What is the variation in energy consumption patterns across households, and which factors are the most important determinants of this variation? (2) How does the fuel mix, particularly between biomass and commercial fuels, differ by income levels? (3) What other factors in addition to income might contribute to the energy transition?

\section{Rural household energy use in 1999}

Analysis of the 1999 rural household survey data shows that the average household total energy consumption is 1345 standard coal equivalent (kgce). The average household size in the survey is 4.05 , so per capita rural residential energy use is $332 \mathrm{kgce}$. Table 2 shows the decomposition of average total energy use by fuel type, indicating that biomass is still the main source, accounting for $72 \%$ of total energy use. Data from earlier years of this survey show that its proportion has decreased relative to the period 1987-1992 (ESMAP 1996). Note that this trend is consistent with the data presented in Figure 2, although the magnitude of the biomass proportion appears to be higher in the survey data than in the aggregate statistics. ${ }^{5}$ The commercial sources (coal, electricity, and LPG+) account for the remaining $28 \%$ of energy use.

Table 2. Rural household energy consumption by energy types in 1999.

\begin{tabular}{lrr}
\hline & Per capita & $\%$ \\
\hline Fuelwood \& straw & 236 & 71 \\
Charcoal & 4 & 1 \\
Total biomass & 240 & 72 \\
Coal & 50 & 15 \\
Coal product & 21 & 6 \\
Electricity & 17 & 5 \\
LPG+ & 5 & 1 \\
Total commercial energy & 92 & 28 \\
Total & 332 & 100 \\
\hline
\end{tabular}

\footnotetext{
${ }^{5}$ Previous survey studies (e.g., ESMAP 1996) also indicate that the aggregate statistics on rural household energy use (biomass in particular) underreport the actual amount of energy (biomass) use.
} 
Regional differences in rural household energy consumption are tremendous. Figure 5 shows per capita energy use of rural households for 31 provinces (or municipalities, autonomous regions) by geographic region. Within each regional group, provinces are arranged from left to right in ascending order of per capita net income. There is no discernable relationship between energy consumption and income across provinces within each region. It appears that resource availability may be a key determinant of the types of energy consumed in each province. For example, provinces that are rich in coal resources (Shanxi, Hebei, Guizhou, Yunnan, Xinjiang, and Ningxia) have large proportions of coal use; rural households of the municipalities (Beijing, Shanghai, and Tianjin) consume significantly more electricity, likely due to better access to, and higher quality of, electricity supplies. Weather conditions are also likely to play a role. As shown in Table 3, per capita energy use is significantly higher in the north than in the south, since households in the north spend much more energy for heating in the winter. Although it is hotter in the summer in the south, air conditioning is not yet prevalent in rural areas and therefore energy used for cooling in the summer is not important. Furthermore, the geographic setting of rural households may also affect their energy use. Hilly areas ${ }^{6}$ use more energy because of a larger consumption of biomass; households in the plains consume more electricity, coal product and LPG+, likely due to the better accessibility of these fuels in the more developed east regions and close to the urban cities.

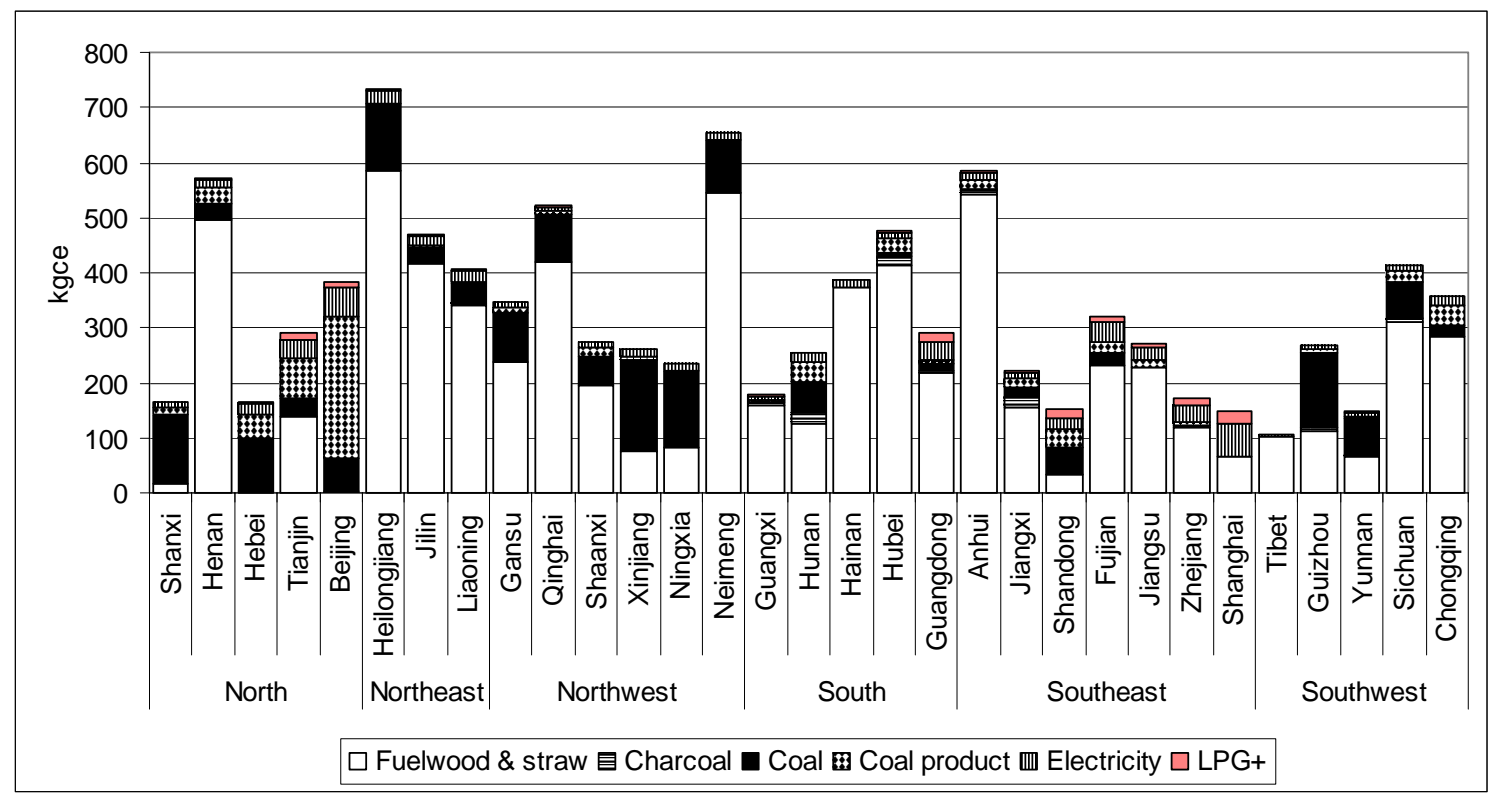

Figure 5. Per capita energy use of rural households by provinces.

\footnotetext{
${ }^{6}$ According to the Rural Household Survey (State Statistical Bureau 2001b), areas according to their topographic conditions are divided into the plains (less undulate, low altitude), hilly areas (with connected small hills), and mountainous areas.
} 
Table 3. Per capita energy use of rural household by location (unit: kgce).

\begin{tabular}{lrrrrrrrr}
\hline & Fuelwood & & & Coal & & & & $\%$ \\
\& straw & Charcoal & Coal & product & Electricity & LPG+ & Total & Biomass \\
\hline Northern China & 272 & 0.5 & 81 & 24 & 16 & 2 & 396 & 69 \\
$\quad$ North & 187 & 0.2 & 72 & 49 & 19 & 3 & 330 & 57 \\
$\quad$ Northeast & 452 & 0.1 & 67 & 1 & 21 & 2 & 543 & 83 \\
$\quad$ Northwest & 274 & 1.0 & 101 & 7 & 12 & 1 & 395 & 70 \\
Southern China & 212 & 6.1 & 29 & 19 & 17 & 6 & 289 & 75 \\
$\quad$ South & 239 & 11.9 & 22 & 19 & 16 & 5 & 313 & 80 \\
$\quad$ Southeast & 205 & 3.9 & 16 & 19 & 22 & 10 & 276 & 76 \\
$\quad$ Southwest & 192 & 3.1 & 60 & 18 & 11 & 1 & 285 & 69 \\
Geographic condition & & & & & & & & \\
$\quad$ Plain & 203 & 0.8 & 51 & 30 & 20 & 6 & 311 & 66 \\
$\quad$ Hilly & 282 & 5.0 & 37 & 17 & 17 & 4 & 363 & 79 \\
$\quad$ Mountainous & 238 & 7.8 & 64 & 9 & 12 & 2 & 331 & 74 \\
China & 236 & 3.9 & 50 & 21 & 17 & 5 & 332 & 71 \\
\hline
\end{tabular}

Electricity is now the most widely used energy in rural China $-98 \%$ of the households use electricity ${ }^{7}$ (Table 4). Sixty-three percent of households use biomass, $39 \%$ use coal or coal product, $29 \%$ use LPG+. We also calculated percentages of households using various combinations of energy sources (Table 5). Households using a single type of energy are rare. More than $97 \%$ of households use at least two types of energy. Biomass plus electricity is the most common combination. Thirty-five percent of households use this combination, a figure that rises to $66 \%$ if households that also use coal (16\%), LPG+ (11\%), or both (4\%) are added. While biomass plus electricity (with or without complementing the use of other fuels) accounts for two-thirds of rural households, the two fuel types do not play an equal role. Biomass is always the dominant source of total energy consumption, while electricity accounts for $3-5 \%$ on average. If coal is used, it accounts for $25-30 \%$ of total energy consumption; if LPG+ is used, it only accounts for $2-3 \%$ of total energy consumption.

If biomass is not used in the household, then coal is usually the main source. Coal plus electricity (13.8\%), and coal plus electricity and LPG+ (7.8\%) account for another $22 \%$ of households. Only $10 \%$ of households use neither biomass nor coal - a category consistent with the typical definition of "modern" energy use patterns - with the most common pattern in this case being electricity plus LPG+ $(8.5 \%)$. Crosstab analysis indicates that professional and more educated people have the highest proportion of this type of energy combination. Moreover, households with the highest incomes are associated with this modern energy use pattern (Table 5), while those who use only biomass or coal have the lowest per capita income. However, as income increases, Chinese rural households add energy types, while total energy consumption does not necessarily increase. Are rich rural households substituting commercial energy for biomass?

\footnotetext{
${ }^{7}$ This is close to the statistics provided by the State Statistical Bureau (2001a): in 1999, 98.3\% of the townships, $97.8 \%$ of the villages, and $97.4 \%$ of the rural households have access to the power grid.
} 
Table 4. Usage of energy types by rural households.

\begin{tabular}{lcccccccc}
\hline & Electricity & Coal & $\begin{array}{c}\text { Coal } \\
\text { product }\end{array}$ & $\begin{array}{c}\text { Wood \& } \\
\text { straw }\end{array}$ & Charcoal & $\begin{array}{c}\text { Other } \\
\text { fuel }\end{array}$ & $\begin{array}{c}\text { Coal \& coal } \\
\text { product }\end{array}$ & Biomass \\
\hline$\%$ of use & 97.65 & 21.37 & 21.32 & 60.51 & 2.77 & 28.92 & 38.55 & 62.55 \\
\hline
\end{tabular}

Table 5. The combination of energy use by rural households.

\begin{tabular}{|c|c|c|c|c|c|c|c|c|}
\hline & \multirow[b]{2}{*}{$\begin{array}{r}\% \text { of } \\
\text { house- } \\
\text { holds }\end{array}$} & \multicolumn{5}{|c|}{ Per capita energy consumption } & \multirow{2}{*}{$\begin{array}{r}\text { Per } \\
\text { capita } \\
\text { net } \\
\text { income }\end{array}$} & \multirow[b]{2}{*}{$\begin{array}{r}\text { Per capita } \\
\text { total } \\
\text { expenditure }\end{array}$} \\
\hline & & $\begin{array}{r}\text { Total } \\
(\text { kgce }) \\
\end{array}$ & $\begin{array}{r}\% \text { of } \\
\text { biomass } \\
\end{array}$ & $\begin{array}{l}\% \text { of } \\
\text { coal }\end{array}$ & $\begin{array}{l}\% \text { of } \\
\text { elec- } \\
\text { tricity }\end{array}$ & $\begin{array}{r}\% \text { of } \\
\text { other } \\
\text { fuel } \\
\end{array}$ & & \\
\hline Electricity only & 1.25 & 15 & 0 & 0 & 100 & 0 & 2188 & 1389 \\
\hline Biomass only & 1.23 & 414 & 100 & 0 & 0 & 0 & 1548 & 1210 \\
\hline Coal only & 0.20 & 315 & 0 & 100 & 0 & 0 & 1787 & 1337 \\
\hline LPG+ only & 0.15 & 21 & 0 & 0 & 0 & 100 & 2958 & 2023 \\
\hline Biomass + electricity & 34.74 & 429 & 97 & 0 & 3 & 0 & 1947 & 1387 \\
\hline $\begin{array}{l}\text { Biomass + coal + } \\
\text { electricity } \\
\text { Biomass + electricity }\end{array}$ & 16.30 & 519 & 68 & 29 & 3 & 0 & 1938 & 1480 \\
\hline$+\mathrm{LPG}+$ & 11.05 & 428 & 92 & 0 & 5 & 3 & 3046 & 2224 \\
\hline $\begin{array}{l}\text { Biomass }+ \text { coal } \\
\text { Biomass }+ \text { coal }+\end{array}$ & 0.15 & 539 & 67 & 33 & 0 & 0 & 1767 & 1680 \\
\hline LPG + & 0.02 & 393 & 79 & 18 & 0 & 3 & 1719 & 1415 \\
\hline Biomass + LPG+ & 0.14 & 393 & 97 & 0 & 0 & 3 & 2392 & 1598 \\
\hline All types & 4.44 & 494 & 68 & 25 & 5 & 2 & 2967 & 2207 \\
\hline $\begin{array}{l}\text { Coal + electricity } \\
\text { Coal + electricity }+\end{array}$ & 13.89 & 252 & 0 & 94 & 6 & 0 & 2142 & 1433 \\
\hline $\mathrm{LPG}+$ & 7.84 & 238 & 0 & 80 & 12 & 8 & 3259 & 2270 \\
\hline Coal + LPG+ & 0.12 & 325 & 0 & 94 & 0 & 6 & 2795 & 1749 \\
\hline Electricity + LPG + & 8.49 & 53 & 0 & 0 & 61 & 39 & 3698 & 2512 \\
\hline Total & 100.00 & 333 & 72 & 21 & 5 & 1 & 2371 & 1671 \\
\hline
\end{tabular}

To further explore the relationship between income and energy use, we categorize households into deciles of per capita net income and per capita total expenditure respectively, and examine their types and amounts of energy consumption. Two ways of reflecting the income level of a household have been predominant in studies of household energy: reported annual household income converted into per capita terms (Sheinbaum et al. 1996; Wang and Feng 1997; Wang et al. 1999; Wijayatunga and Attalag 2002) and total expenditures per capita (Pitt 1985; Manickam 2000; Reddy 2003). Income as reported in surveys can be a noisy measure of long-term average income flows, particularly in developing country settings. The use of total expenditures may be more reflective of long-term income. On the other hand, analysis in terms of income is often more informative to outlooks for future energy demand, which are typically made in the context of scenarios of future income growth, rather than future consumption. The distinction is likely to be particularly important in China, where the correlation coefficient between per capita net income and per capita expenditure in the 1999 survey data is only 0.516. Table 6 shows that there are substantial numbers of low income households falling into high expenditure groups, and 
high income households belonging to the low expenditure groups. The savings rate in China is high relative to other countries (Feltenstein et al. 1990). The 1999 rural household survey suggests a $20 \%$ savings rate, with the rate increasing with income but decreasing with expenditure. Due to a lack of social insurance and access to bank loans, rural households typically save for large expected or unexpected expenses (e.g., elderly support, house construction, children's education, medical treatment, etc.). Therefore, an increase in income will not automatically imply higher expenditure, since households may choose to save most of the extra income. In addition, high expenditures may be due mainly to less saving. We examine the income effect on rural household energy by separately considering net income and total expenditures.

Table 6. Crosstabs between per capita household income and expenditure.

\begin{tabular}{|c|c|c|c|c|c|c|c|c|c|c|c|}
\hline \multirow{2}{*}{$\begin{array}{l}\text { Expenditure } \\
\text { group }\end{array}$} & \multicolumn{11}{|c|}{ Income group } \\
\hline & 1 & 2 & 3 & 4 & 5 & 6 & 7 & 8 & 9 & 10 & Saving \\
\hline 1 & 37.20 & 19.29 & 13.42 & 8.86 & 6.95 & 5.27 & 3.88 & 2.74 & 1.95 & 0.44 & 37.18 \\
\hline 2 & 23.50 & 19.64 & 15.52 & 11.60 & 8.94 & 7.37 & 5.81 & 4.00 & 2.40 & 1.23 & 31.81 \\
\hline 3 & 13.81 & 18.56 & 15.85 & 12.67 & 11.14 & 9.16 & 7.63 & 5.46 & 3.74 & 1.98 & 32.55 \\
\hline 4 & 8.32 & 15.06 & 15.12 & 14.87 & 12.29 & 10.40 & 9.15 & 7.07 & 5.24 & 2.45 & 27.52 \\
\hline 5 & 5.76 & 9.95 & 13.34 & 15.09 & 13.55 & 12.34 & 11.41 & 9.02 & 6.23 & 3.30 & 22.74 \\
\hline 6 & 3.81 & 6.62 & 10.57 & 13.08 & 14.73 & 14.92 & 12.23 & 10.82 & 8.77 & 4.45 & 23.11 \\
\hline 7 & 2.90 & 4.42 & 7.78 & 10.83 & 13.48 & 14.60 & 14.41 & 13.11 & 11.68 & 6.80 & 18.32 \\
\hline 8 & 2.22 & 2.88 & 4.44 & 6.56 & 10.15 & 13.20 & 15.56 & 17.74 & 15.63 & 11.62 & 12.52 \\
\hline 9 & 1.39 & 1.93 & 2.66 & 4.09 & 5.60 & 8.86 & 13.38 & 18.77 & 23.02 & 20.31 & 6.82 \\
\hline 10 & 1.14 & 1.31 & 1.70 & 2.32 & 3.22 & 3.88 & 6.51 & 11.31 & 21.24 & 47.37 & -33.63 \\
\hline Saving & -49.31 & 1.77 & 13.46 & 18.48 & 24.42 & 28.76 & 31.28 & 33.02 & 35.93 & 41.06 & \\
\hline
\end{tabular}

Our analysis indicates that rural household per capita expenditure on energy in 1999 was 56.3 yuan (or US\$ 6.8) which represents $3.4 \%$ of total expenditures and $2.3 \%$ of income. In general energy expenditures increase with income and total expenditure, and in both cases the share of energy expenditures on coal declines, on LPG+ increases, and on electricity remains roughly constant (Figure 6). This indicates that as either income or expenditures increase, households may prefer more convenient, efficient and cleaner LPG to coal, while their expenditure on electricity increases proportionately. However, the patterns according to income or expenditure differ in one respect: as income increases, households spend proportionately more on energy goods as a group, while as expenditure grows, the budget share for energy does not change much (Figure 7). 
a)

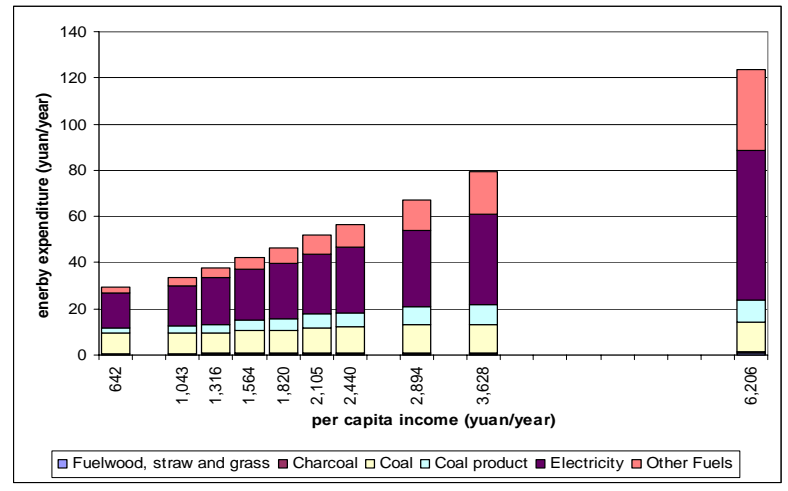

c)

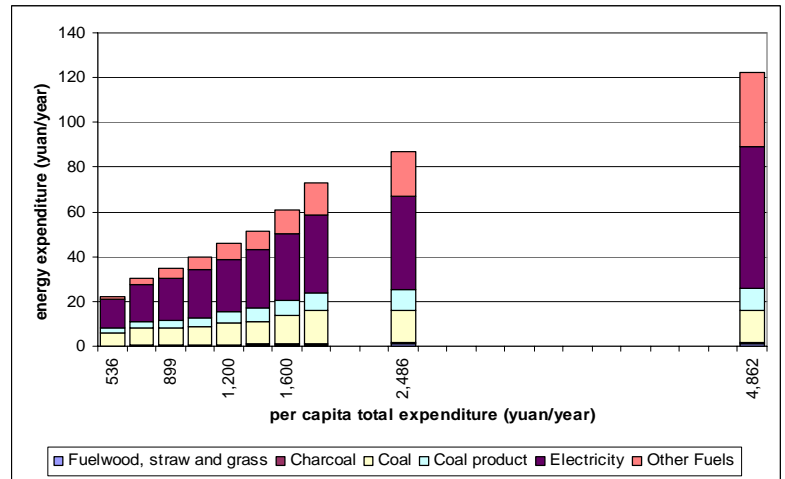

b)

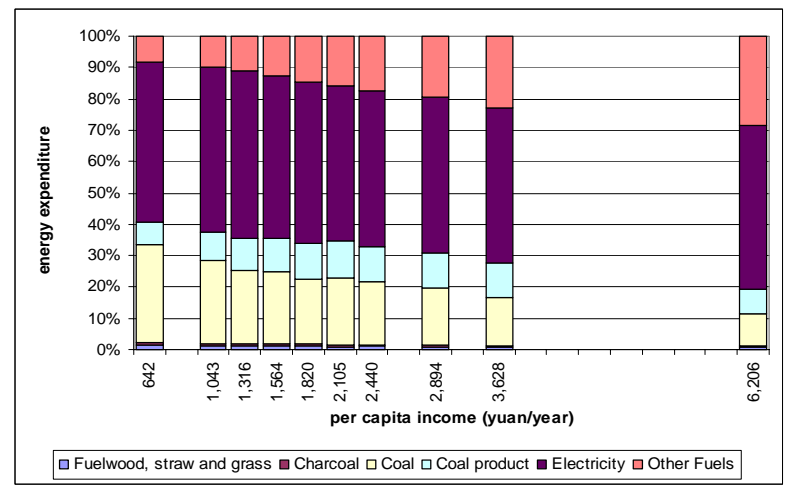

d)

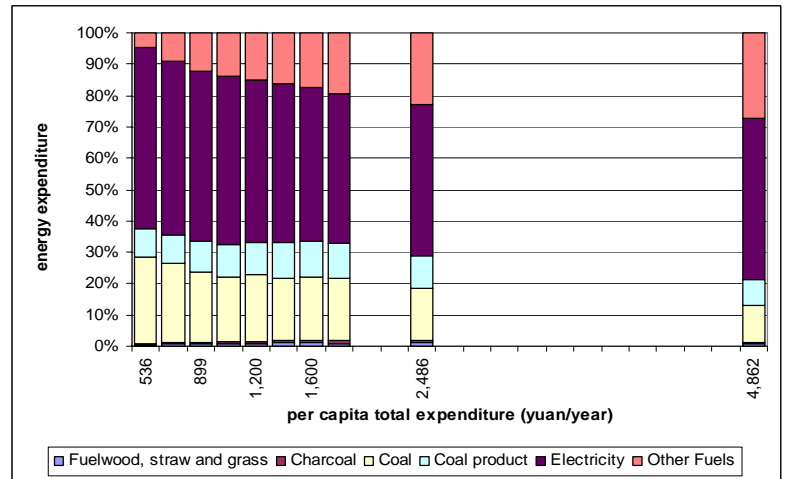

Figure 6. Rural household energy expenditure by fuel type for deciles of per capita income $(a, b)$ and per capita total expenditures $(c, d)$.

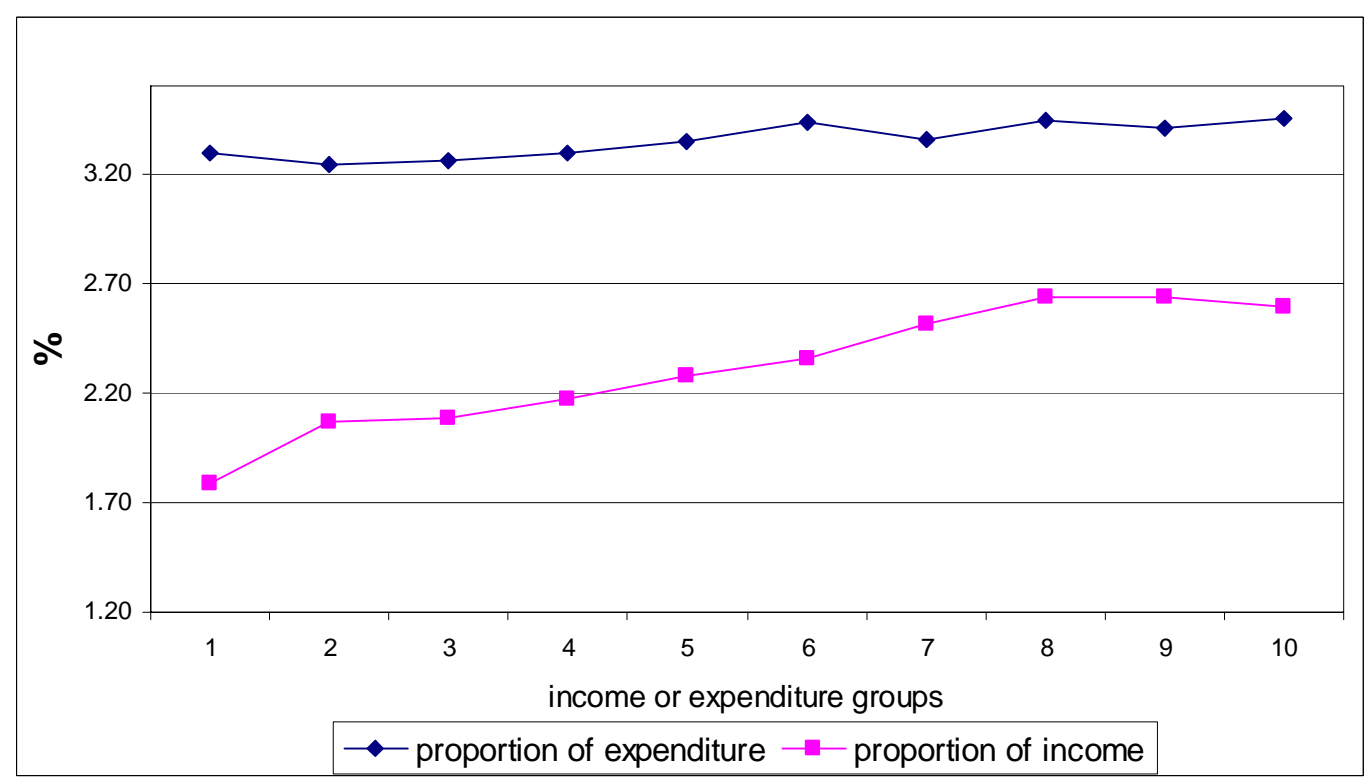

Figure 7. Energy expenditures as a proportion of income or total expenditure, by income or expenditure group. 
The discussion of budget shares can only capture some of the features of energy consumption of rural households by income levels. One complicating factor is regional variation in energy prices, which can lead comparisons of consumption shares to be different than comparisons of budget shares. Furthermore, a comparison of budget shares cannot reflect changes in biomass use with income or expenditures, because rural households mainly collect biomass themselves rather than purchase it on the market. Therefore, we analyze the actual amount of energy consumed by income levels. Figures $8 \mathrm{a}-\mathrm{b}$ indicate that the quantity of biomass consumed remains roughly constant within the $80 \%$ interval of per capita income. The highest and lowest income deciles show a decrease in biomass use. Commercial energy use increases slightly across income groups, resulting in a decline in the proportion of biomass use with income, especially for the highest income groups. This suggests that biomass may not be substituted by commercial energy sources until household income reaches a rather high level.

a)

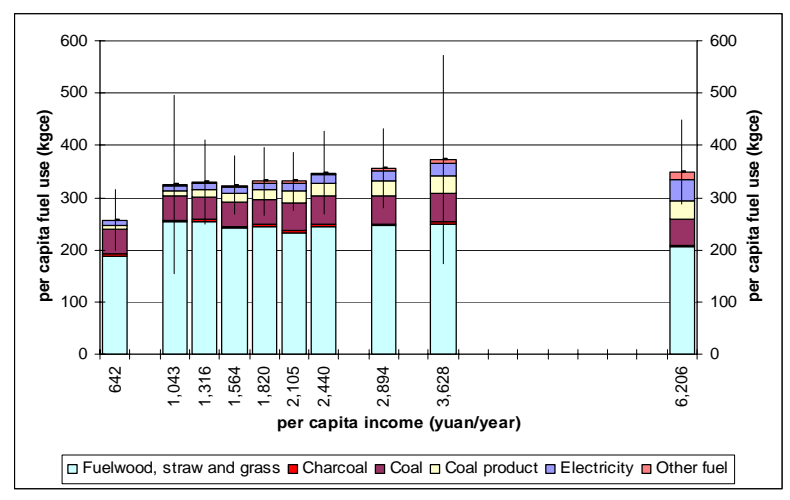

c)

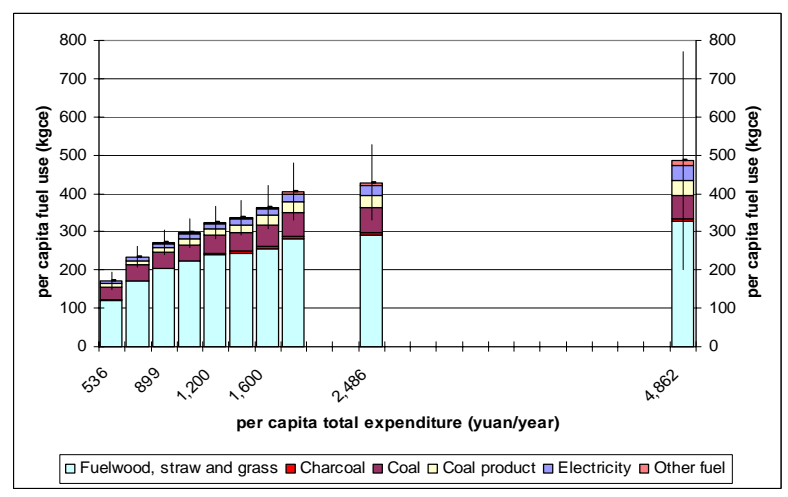

b)

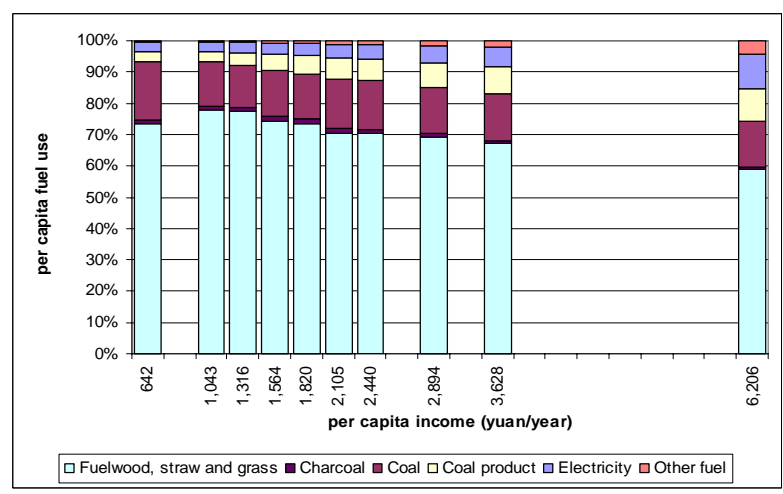

d)

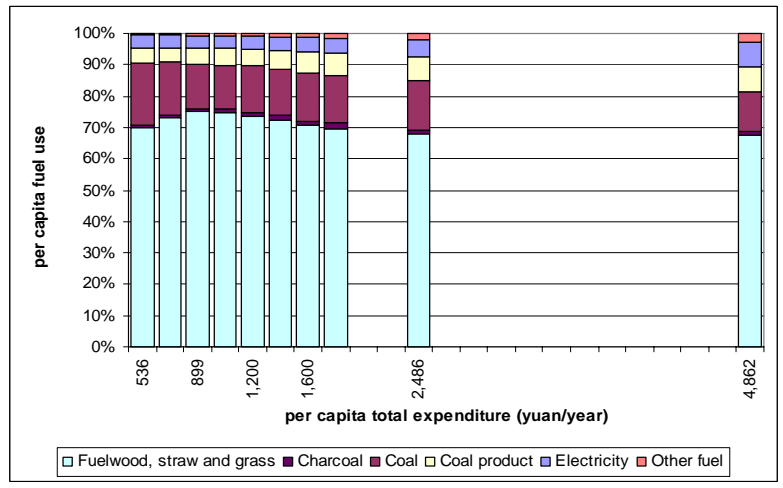

Figure 8. Rural household energy consumption by income and expenditure groups.

Statistical analysis also shows that although the number of domestic appliances (except black and white TV sets) ${ }^{8}$ generally increases with income (Figure 9), there is a

\footnotetext{
${ }^{8}$ Black and white TV set is substituted by color TV set.
} 
significant increase in the highest income group. In particular, this is the case for refrigerators and air conditioners, which use the most electricity in modern households. The number of refrigerators is almost doubled (from 18 of the 80 percentile to 36 of the 90 percentile) and the number of air conditioners increases by four times (from 1 of the 80 percentile to 4 percentile of the 90 percentile). Therefore, one may expect a major increase in commercial energy use with further income growth.

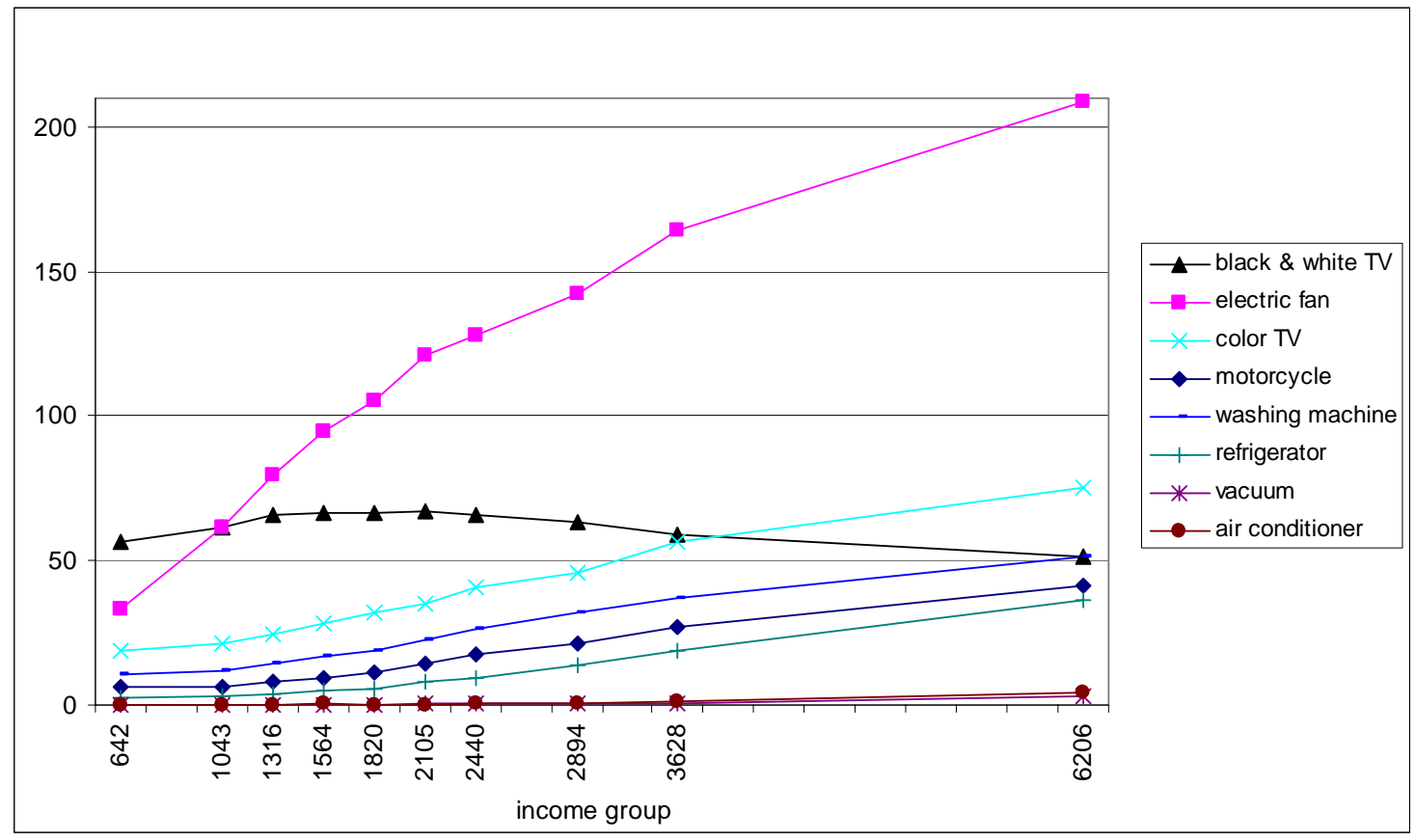

Figure 9. Domestic appliance per 100 rural households by income.

Analyzing energy use by household expenditure (Figures 8c-d), we find a substantially different set of relationships. As expenditure increases, all types of energy consumption increase accordingly, and the proportion of energy from biomass use declines very little. Households with high expenditure essentially consume a smaller share of coal, and a larger share of modern energy sources (electricity and LPG+) as well as coal product. Consequently there is not a clear transition from biomass to commercial energy. What we observe is an increase of energy consumption of all fuel types with expenditure, while those with higher expenditures spend slightly more on more convenient, efficient fuels.

Therefore, judging by the statistics from the 1999 rural household survey, the energy transition among rural households in present-day China is still in an early stage. With further socioeconomic development and increases of income, biomass will likely be substituted by modern fuels, but this process may be slow. Currently, the crosssectional data suggest that income increases may have to be substantial (into the top decile of current income) before the absolute amount of biomass use declines. This conclusion must be tentative, based as it is on cross-sectional analysis. Moreover, we find that using total expenditures as the indicator of income does not capture the phenomenon of the energy transition. Differences in household expenditure are induced 
not only by income levels but also by changes in markets, values, lifestyles, and other socio-demographic characteristics of households.

We further investigate the main driving forces of the energy transition in rural households by considering factors in addition to income and expenditure. We carry out two regression analyses. First, we model the use (versus non-use) of biomass as a function of socioeconomic, demographic and geographic characteristics of households. The logistic regression model takes as its dependent variable whether or not the household uses biomass. Independent variables include household size; household structure; age, sex, education and occupation of householder; geographic condition; location; per capita income; and per capita expenditure. Results are shown in Table 7, and indicate that all these factors, except for household structure and age of the head, are significant determinants of whether a household uses biomass. The order of importance of the variables is location, geographic condition, income, occupation, education, household size, expenditure, and sex. Specifically, households in the northeast, south, or southwest are more likely to use biomass than households in the north, southeast or northwest; households in the plains use biomass less frequently than those in mountainous and hilly areas. These results most likely reflect differences in accessibility of natural resources. As income and expenditure increase, the likelihood of using biomass decreases. Moreover, households headed by a professional are significantly less likely to use biomass; as the educational level of the head increases, the likelihood of the household using biomass decreases. Smaller households, and those headed by females, are less likely to use biomass.

Table 7. Logistic regression analysis of the use versus non-use of biomass by rural households. Notes: B is the coefficient; S.E. is the standardized error; Wald is an index indicating the significance of the independent variable; Sig. stands for significance; $\operatorname{Exp}(B)$ is the exponential of the coefficient. These are the standard output of logistical regression analysis. Pseudo R-Square: Nagelkerke $=0.268$.

\begin{tabular}{|c|c|c|c|c|c|c|c|c|}
\hline & & \multirow[t]{2}{*}{ B } & \multirow[t]{2}{*}{ S. E. } & \multirow[t]{2}{*}{ Wald } & \multirow[t]{2}{*}{ Sig. } & \multirow[t]{2}{*}{$\operatorname{Exp}(B)$} & \multicolumn{2}{|c|}{$\begin{array}{l}95 \% \text { confidence } \\
\text { interval for } \\
\operatorname{Exp}(\mathrm{B})\end{array}$} \\
\hline & & & & & & & Lower & Upper \\
\hline & Intercept & -0.22 & 0.33 & 0.44 & 0.51 & & & \\
\hline \multirow[t]{2}{*}{ Sex } & Male & -0.32 & 0.06 & 26.25 & 0.00 & 0.73 & 0.65 & 0.82 \\
\hline & Female & 0.00 & & & & & & \\
\hline \multirow[t]{6}{*}{ Education } & Illiterate & -0.73 & 0.20 & 13.70 & 0.00 & 0.48 & 0.33 & 0.71 \\
\hline & Primary & -0.71 & 0.19 & 13.60 & 0.00 & 0.49 & 0.34 & 0.72 \\
\hline & Junior middle school & -0.60 & 0.19 & 9.82 & 0.00 & 0.55 & 0.38 & 0.80 \\
\hline & Junior middle school & -0.54 & 0.19 & 7.71 & 0.01 & 0.58 & 0.40 & 0.85 \\
\hline & Vocational & -0.36 & 0.21 & 2.97 & 0.09 & 0.70 & 0.47 & 1.05 \\
\hline & College and above & 0.00 & & & & & & \\
\hline \multirow[t]{4}{*}{ Occupation } & Village cadre & -0.02 & 0.07 & 0.06 & 0.81 & 0.98 & 0.87 & 1.12 \\
\hline & Professional & 0.40 & 0.05 & 67.90 & 0.00 & 1.49 & 1.36 & 1.64 \\
\hline & TVE worker and others & 0.05 & 0.05 & 0.95 & 0.33 & 1.05 & 0.95 & 1.15 \\
\hline & Farmer & 0.00 & & & & & & \\
\hline
\end{tabular}




\begin{tabular}{|c|c|c|c|c|c|c|c|c|}
\hline \multirow{3}{*}{$\begin{array}{l}\text { Geographic } \\
\text { condition }\end{array}$} & Plain & 0.55 & 0.03 & 371.64 & 0.00 & 1.73 & 1.64 & 1.83 \\
\hline & Hilly & 0.24 & 0.03 & 64.47 & 0.00 & 1.27 & 1.20 & 1.35 \\
\hline & Mountainous & 0.00 & & & & & & \\
\hline \multirow{8}{*}{$\begin{array}{l}\text { Household } \\
\text { size }\end{array}$} & 1 & 0.41 & 0.31 & 1.69 & 0.19 & 1.50 & 0.81 & 2.77 \\
\hline & 2 & 0.18 & 0.16 & 1.37 & 0.24 & 1.20 & 0.88 & 1.64 \\
\hline & 3 & 0.24 & 0.08 & 8.35 & 0.00 & 1.27 & 1.08 & 1.49 \\
\hline & 4 & 0.26 & 0.08 & 10.50 & 0.00 & 1.29 & 1.11 & 1.51 \\
\hline & 5 & 0.18 & 0.08 & 5.43 & 0.02 & 1.20 & 1.03 & 1.40 \\
\hline & 6 & 0.10 & 0.08 & 1.55 & 0.21 & 1.11 & 0.94 & 1.30 \\
\hline & 7 & 0.01 & 0.09 & 0.01 & 0.91 & 1.01 & 0.84 & 1.21 \\
\hline & $8+$ & 0.00 & & & & & & \\
\hline \multirow{8}{*}{$\begin{array}{l}\text { Household } \\
\text { structure }\end{array}$} & One person & 0.00 & & & & & & \\
\hline & One couple & 0.22 & 0.27 & 0.64 & 0.42 & 1.24 & 0.73 & 2.12 \\
\hline & Couple and child & -0.08 & 0.25 & 0.09 & 0.76 & 0.93 & 0.57 & 1.51 \\
\hline & Single-mother and child & -0.25 & 0.27 & 0.88 & 0.35 & 0.78 & 0.46 & 1.32 \\
\hline & Single-father and child & 0.03 & 0.27 & 0.01 & 0.92 & 1.03 & 0.61 & 1.74 \\
\hline & Grandparent-grandchild & 0.51 & 0.31 & 2.81 & 0.09 & 1.67 & 0.92 & 3.04 \\
\hline & Three and more generation & -0.12 & 0.25 & 0.21 & 0.64 & 0.89 & 0.54 & 1.46 \\
\hline & Others & 0.00 & & & & & & \\
\hline \multirow[t]{6}{*}{ Location } & North & 2.25 & 0.04 & 2917.14 & 0.00 & 9.49 & 8.74 & 10.29 \\
\hline & Northeast & -1.12 & 0.06 & 328.66 & 0.00 & 0.32 & 0.29 & 0.37 \\
\hline & Northwest & 0.87 & 0.04 & 479.57 & 0.00 & 2.39 & 2.21 & 2.58 \\
\hline & South & -0.09 & 0.04 & 4.73 & 0.03 & 0.91 & 0.84 & 0.99 \\
\hline & Southeast & 0.75 & 0.04 & 410.48 & 0.00 & 2.11 & 1.96 & 2.27 \\
\hline & Southwest & 0.00 & & & & & & \\
\hline \multirow{5}{*}{$\begin{array}{l}\text { Income } \\
\text { group }\end{array}$} & $20 \%$ & -0.53 & 0.04 & 155.33 & 0.00 & 0.59 & 0.54 & 0.64 \\
\hline & $40 \%$ & -0.57 & 0.04 & 219.51 & 0.00 & 0.56 & 0.52 & 0.61 \\
\hline & $60 \%$ & -0.49 & 0.04 & 182.47 & 0.00 & 0.61 & 0.57 & 0.66 \\
\hline & $80 \%$ & \begin{tabular}{|c|}
-0.31 \\
\end{tabular} & 0.03 & 82.24 & 0.00 & 0.73 & 0.69 & 0.79 \\
\hline & $100 \%$ & 0.00 & & & & & & \\
\hline \multirow{5}{*}{$\begin{array}{l}\text { Expenditure } \\
\text { group }\end{array}$} & $20 \%$ & 0.00 & 0.04 & 0.01 & 0.91 & 1.00 & 0.92 & 1.08 \\
\hline & $40 \%$ & -0.16 & 0.04 & 16.78 & 0.00 & 0.85 & 0.79 & 0.92 \\
\hline & $60 \%$ & -0.14 & 0.04 & 14.20 & 0.00 & 0.87 & 0.81 & 0.94 \\
\hline & $80 \%$ & \begin{tabular}{|c|}
-0.10 \\
\end{tabular} & 0.03 & 9.16 & 0.00 & 0.90 & 0.84 & 0.96 \\
\hline & $100 \%$ & 0.00 & & & & & & \\
\hline
\end{tabular}

Next, we explore determinants of energy use by constructing a linear regression model that predicts rural household energy use as a function of energy accessibility, price, climate, geographic condition, household income, expenditure, and other demographic characteristics. For energy accessibility, we obtained data on forest coverage (China Academy of Forest Research 2003) and urbanization levels of each province (State Statistical Bureau 2001a), and the 1999 provincial per capita production of coal, gas, petroleum, and electricity (Department of Industry and Transportation 
Statistics, National Bureau of Statistics 2001). Geographic condition is also used to indicate differences in energy accessibility. Moreover, we use the 1999 average temperature of the provincial capital cities (State Statistical Bureau 2001a) together with a dummy variable of location south-north in China as regressors to test the importance of climate differences. Variables for demographic characteristics include household size, age, sex, education, and occupation of the householders. Using these variables, we construct linear regression models for predicting rural household per capita total energy consumption, per capita commercial energy consumption, per capita biomass use, and the ratio of biomass use to total energy use. A stepwise method is used to enter the independent variables. The four regression models are presented in Table 8.

Table 8. Linear regression analysis of rural household energy consumption.

\begin{tabular}{l|l|r|r|r|r|r|r}
\hline & & $\begin{array}{r}\text { Unstandardized } \\
\text { Coefficients }\end{array}$ & Std. Error & $\begin{array}{r}\text { Standardized } \\
\text { Coefficients }\end{array}$ & $\mathrm{t}$ & Sig. \\
\hline \multicolumn{1}{l}{ Dependent variable = Logarithm of per capita energy use; Adjusted $\boldsymbol{R}$ square $=\mathbf{0 . 1 5 0}$} \\
\hline 9 & (Constant) & 6.602 & 0.442 & & 14.948 & 0.000 \\
\hline & LGEXP & 0.431 & 0.017 & 0.170 & 25.314 & 0.000 \\
\hline & SOUNORTH & 0.737 & 0.035 & 0.236 & 21.290 & 0.000 \\
\hline & LGYTEMP & -0.906 & 0.045 & -0.238 & -20.030 & 0.000 \\
\hline & LGCPROD & -0.412 & 0.022 & -0.187 & -18.456 & 0.000 \\
\hline & LGEPROD & -0.713 & 0.039 & -0.141 & -18.106 & 0.000 \\
\hline & LGURBAN & 0.901 & 0.050 & 0.174 & 17.832 & 0.000 \\
\hline & LGELEPRC & 1.867 & 0.124 & 0.144 & 15.114 & 0.000 \\
\hline & HHSIZE & -0.075 & 0.007 & -0.066 & -10.274 & 0.000 \\
\hline & GEOCON & 0.118 & 0.012 & 0.062 & 9.744 & 0.000 \\
\hline Dependent variable $=$ Logarithm of per capita biomass & use; Adjusted $\boldsymbol{R}$ square=0.312 & \\
\hline 14 & (Constant) & 21.39646389 & 0.553103 & & 38.6844 & $1.86 \mathrm{E}-23$ \\
\hline & LGOPROD & 0.278 & 0.021 & 0.464 & 13.054 & 0.000 \\
\hline & LGYTEMP & -4.403 & 0.144 & -1.800 & -30.581 & 0.000 \\
\hline & HHSIZE & -0.151 & 0.007 & -0.179 & -21.611 & 0.000 \\
\hline & SOUNORTH & 1.352 & 0.067 & 0.574 & 20.094 & 0.000 \\
\hline & LGELEPRC & 3.552 & 0.182 & 0.352 & 19.542 & 0.000 \\
\hline & LGFOREST & -0.269 & 0.016 & -0.283 & -17.034 & 0.000 \\
\hline & LGEPROD & -1.239 & 0.076 & -0.367 & -16.276 & 0.000 \\
\hline & LGCPROD & -0.430 & 0.027 & -0.289 & -15.712 & 0.000 \\
\hline & LGGPROD & -0.240 & 0.015 & -0.399 & -15.601 & 0.000 \\
\hline & LGCOAPRC & 0.217 & 0.020 & 0.091 & 11.071 & 0.000 \\
\hline & LGEXP & 0.167 & 0.017 & 0.084 & 9.910 & 0.000 \\
\hline & LGURBAN & -0.477 & 0.116 & -0.124 & -4.118 & 0.000 \\
\hline
\end{tabular}




\begin{tabular}{|c|c|c|c|c|c|c|}
\hline \multicolumn{7}{|c|}{$\begin{array}{l}\text { Dependent variable }=\text { Logarithm of per capita commercial energy use; } \text { Adjsuted } R \\
\text { square }=0.162\end{array}$} \\
\hline \multirow[t]{8}{*}{9} & (Constant) & -16.932 & 0.475 & & -35.663 & 0.000 \\
\hline & LGEPROD & 1.523 & 0.050 & 0.304 & 30.725 & 0.000 \\
\hline & LGCPROD & 0.692 & 0.023 & 0.331 & 30.355 & 0.000 \\
\hline & LGEXP & 0.521 & 0.022 & 0.214 & 23.492 & 0.000 \\
\hline & LGCOAPRC & -0.643 & 0.029 & -0.176 & -22.456 & 0.000 \\
\hline & LGYTEMP & 1.319 & 0.061 & 0.223 & 21.487 & 0.000 \\
\hline & HHSIZE & -0.068 & 0.009 & -0.058 & -7.457 & 0.000 \\
\hline & LGINCOME & 0.142 & 0.024 & 0.056 & 5.993 & 0.000 \\
\hline \multicolumn{7}{|c|}{ Dependent variable $=$ Proportion of biomass use $;$ Adjsuted $R$ square $=0.322$} \\
\hline \multirow[t]{9}{*}{8} & (Constant) & 959.477 & 14.228 & & 67.437 & 0.000 \\
\hline & LGCPROD & -39.080 & 0.719 & -0.646 & -54.375 & 0.000 \\
\hline & LGYTEMP & -83.529 & 1.650 & -0.487 & -50.638 & 0.000 \\
\hline & LGEPROD & -78.229 & 1.627 & -0.539 & -48.083 & 0.000 \\
\hline & LGCLPPRC & 21.990 & 0.802 & 0.208 & 27.407 & 0.000 \\
\hline & LGINCOME & -7.088 & 0.528 & -0.096 & -13.432 & 0.000 \\
\hline & GEOCON & 4.431 & 0.389 & 0.079 & 11.390 & 0.000 \\
\hline & LGCOAPRC & 5.264 & 0.726 & 0.056 & 7.252 & 0.000 \\
\hline & LGOPROD & 2.016 & 0.281 & 0.065 & 7.181 & 0.000 \\
\hline
\end{tabular}

Note: LGEXP- logarithm of per capita expenditure;

LGINCOME - logarithm of per capita household net income;

SOUNORTH - location of south or north in China;

GEOCON - geographic condition of the household;

LGYTEMP - logarithm of the 1999 yearly temperature of the provincial capital cities;

LGCPROD - logarithm of the 1999 provincial coal production;

LGEPROD - logarithm of the 1999 provincial electricity production;

LGGPROD - logarithm of the 1999 provincial gas production;

LGOPROD - logarithm of the 1999 provincial petroleum production;

LGCOAPRC - logarithm of the coal price

LGELEPRC - logarithm of the electricity price

LGOFULP - logarithm of the other fuel price

LGURBAN - logarithm of the provincial urbanization level

LGFOREST - logarithm of the provincial forest coverage

HHSIZE - household size

Results show that, except for household size, other household demographic characteristics are excluded from the models. Moreover, although the number of predictors in all the models is rather large, the adjusted $\mathrm{R}$ square is not very high, indicating that factors influencing energy consumption may be complex and that important factors may be left out of these models. Another possible explanation of low adjusted $\mathrm{R}$ square values for the models is that many of the independent variables in our analysis only offer information at the aggregate provincial level, and variations across households within the provinces are masked. We tried calculating the proportion of 
energy use by types for each village and using these values as the indicator of energy accessibility. This approach doubled the adjusted $\mathrm{R}$ square values of the models. However, the proportion of energy use by types is not only affected by accessibility, but also affected by other variables such as income, etc., that have a direct influence on the amount of energy use. We eventually decided not use these village-level variables in the regression analysis.

For per capita total energy use, household expenditure is the most powerful predictor, followed by south/north location and yearly temperatures - households in the north and in regions with low temperature consume more. Coal production, electricity production and price are also important - if the region has good access to coal and electricity, households use less total energy due to less use of biomass. Household size is negatively related to total energy use; urbanization level increases energy use, and mountainous areas consume more since they have relatively better access to biomass resources and poorer access to commercial energy.

For commercial energy use, coal and electricity accessibility are the most important predictors, while expenditure, household size and yearly temperature also play important roles. However, per capita net income is also included in the model, which indicates that income growth increases the amount of commercial energy consumption.

For per capita biomass use, climate is important (represented by south/north location); household size and expenditure also play a role. Accessibility to a commercial energy source shows different impacts. On the one hand, the impacts of production and prices of electricity, coal, and gas indicate that accessibility of these energy sources decrease the amount of biomass use. On the other hand, rural households in areas with high petroleum production consume more biomass, which implies that petroleum is not used widely by rural households and has little impact on substitution for biomass. That urbanization negatively relates to biomass use indicates that urban growth may save biomass used as an energy source. Moreover, the fact that forest coverage also negatively relates to biomass use contradicts the assumption that biomass accessibility contributes to the use of biomass. To explain this phenomenon, we might need to change our idea about high forest coverage from a cause of more biomass use to a consequence of less biomass use.

In the model of the ratio of biomass to total energy, the accessibility of coal and electricity are again the most important predictors; yearly average temperature also has a strong effect. Petroleum production is positively related to biomass use proportion as in the model above. However, it is noted that geographic condition positively relates to biomass proportion, which verifies the assumption that biomass use is more popular in hilly and mountainous areas than in the plains. More importantly, increase of per capita net income decreases biomass proportion, while expenditure is not included in the model any more. Therefore, improved income contributes to the energy transition, whereas increased expenditures in general only increase the total amount of energy as well as biomass consumption. 


\section{Conclusion and Discussion}

Based on an analysis of a nationally representative cross-sectional rural household survey and historical aggregate statistics, we show that residential energy consumption in rural China is undergoing an energy transition away from traditional biomass and toward commercial energy sources. This process is still in an early stage, given that biomass still accounts for about two-thirds of the total energy use by rural households. Energy use varies tremendously across regions both in total and by fuel type, given the differences in available energy sources, prices, climate, income, and urbanization levels. Cross-sectional data show that biomass use falls in absolute terms only at the highest levels of household income. This suggests that declines in aggregate biomass use may be slow, although this conclusion must remain tentative since it is based on crosssectional data. Further work with data from additional points in time would be valuable. We also examined patterns of energy use as a function of both income and of total expenditure, since both variables are used in the literature describing energy transitions. We find that patterns as a function of total expenditure do not fit the energy transition model, while those as a function of reported income do. Moreover, while the transition is occurring, the commercial energy source which appears to be the principal substitute for biomass in rural households is coal - electricity, while used in nearly all households, does not yet account for a substantial fraction of energy use. Given that burning coal in the household is a major contributor of air pollution in China, further transition to modern and clean fuels such as natural gas and electricity is important. Further income growth induced by socioeconomic development and improvement of modern energy accessibility will play critical roles in the transition.

Finally, regression analysis suggests that accessibility (and quality) of energy resources is a key determinant of energy use. Thus, as changes occur in the relative accessibility of biomass versus commercial sources such as coal and electricity, additional shifts in energy use should be expected.

\section{References}

Adeoti, O., D.O.O. Idowu, and T. Falegan. 2001. Could fuelwood use contribute to household poverty in Nigeria? Biomass \& Bioenergy 21: 205-210.

China Academy of Forest Research. 2003. The Fifth Investigation of Forest Resource. http://211.144.19.144/dataquery/ (access date: August 14, 2003).

Davis, M. 1998. Rural household energy consumption, the effects of access to electricity - evidence from South Africa. Energy Policy 26(3): 207-217.

Department of Industry and Transportation Statistics, National Bureau of Statistics. 2001. China Energy Statistical Yearbook 1997-1999. Beijing: China Statistics Press.

ESMAP. 1996. Energy for Rural Development in China: An Assessment Based on a Joint Chinese/ESMAP Study in Six Counties. Report No. 183/96. Washington, D.C.: The World Bank, Energy Sector Management Assistance Programme.

Feltenstein, A., D. Lebow, and S. Van Wijnbergen. 1990. Savings, commodity market rationing, and the real rate of interest in China. Journal of Money, Credit and Banking 22(2): 234-252. 
Foley, G. 1995. Photovoltaic Applications in Rural Areas of the Developing World. ESMAP Technical Paper 009. Washington, D.C.: The World Bank, Energy Sector Management Assistance Programme.

Foster, V, J.-P. Tre, and Q. Wodon. 2000. Energy Consumption and Income: An Inverted-U at the Household Level? Washington, D.C.: The World Bank.

Fridley, D., J. Sinton, and J. Lewis. 2003. Working out the kinks: Understanding the fall and rise of energy use in China. Working Paper LBNL-52271. Berkeley, CA: Lawrence Berkeley National Laboratory.

Leach, G. 1992. The energy transition. Energy Policy 20(2): 116-123.

Leach, G. and M. Gowan. 1987. Household Energy Handbook, An Interim Guide and Reference Manual. Washington, D.C.: The World Bank.

Manickam, M. 2000. Hot Wired or Wood Fired? Determinants of Fuel Choice in Indonesia. Senior thesis for a Bachelor degree with honors in environmental studies, Brown University, USA.

Pitt, M.M. 1985. Equity, externalities and energy subsidies - the case of kerosene in Indonesia. Journal of Development Economics 17: 201-217.

Reddy, B.S. 2003. Overcoming the energy efficiency gap in India's household sector. Energy Policy 31: 1117-1127.

Sheinbaum, C., M. Martinez, and L. Rodriguez. 1996. Trends and prospects in Mexican residential energy use. Energy 21(6): 493-504.

Sinton, J.E. and D.G. Fridley. 2002. A guide to China's energy statistics. The Journal of Energy Literature, Vol. VIII, No. 1.

State Statistical Bureau. 2001a. China Statistics Yearbook, 2000. Beijing: China Statistics Press.

State Statistical Bureau. 2001b. Rural Household Survey. Beijing: China Statistics Press.

Transportation and Energy Department, State Planning Committee. 1997. Energy Saving in China. Beijing: China Electricity Press.

Wang Xiaohua and Feng Zhenmin. 1997. Rural household energy consumption in Yangzhong County of Jiangsu Province in China. Energy 22(12): 1159-1162.

Wang Xiaohua and Feng Zhenmin. 2001. Rural household energy consumption with the economic development in China: Stages and characteristics indices. Energy Policy 29: 1391-1397.

Wang Xiaohua, Dai Xiaqing, and Zhou Yuedong. 2002. Domestic energy consumption in rural China: A study on Sheyang County of Jiangsu Province. Biomass \& Bioenergy 22: 251-256.

Wang Xiaohua, Feng Zhenming, and Ding Qishuo. 1999. Increased energy use in Jangsu Province of China with protection of the environment. Energy 24: 413417. 
Wijayatunga, P.D.C. and R.A. Attalag. 2002. Analysis of household cooking energy demand and its environmental impact in Sri Lanka. Energy Conversion \& Management 43: 2213-2223.

World Energy Council. 1999. The Challenge of Rural Energy Poverty in Developing Countries. Rome: World Energy Council and Food and Agriculture Organization of the United Nations. 